\title{
KEPEMIMPINAN DALAM PERSPEKTIF ISLAM DAN DASAR KONSEPTUALNYA
}

\author{
Maimunah \\ Dosen Manajemen Pendidikan Islam Univeristas Islam Indragiri \\ e-mail: alhafizza@gmail.com
}

\begin{abstract}
Abstrak
Kepemimpinan Adalah cara untuk memimpin, sedikitnya terdapat empat alasan mengapa seorang pemimpin dibutuhkan. Pertama, secara alamiah manusia butuh untuk diatur. Kedua, dalam beberapa situasi seorang pemimpin perlu tampil mewakili kelompoknya. Ketiga, sebagai tempat pengambil alih resiko apabila terjadi tekanan terhadap kelompoknya. Keempat, sebagai tempat untuk meletakkan kekuasaan. Imamah atau kepemimpinan Islam adalah konsep yang tercantum dalam Al-Qur'an dan Assunah, yang meliputi kebutuhan manusia dari pribadi, keluarga, bahkan sampai ummat manusia atau kelompok. Konsep ini mencakup baik cara-cara memimpin demi terlaksananya ajaran Islam untuk menjamin kehidupan yang lebih baik di dunia dan akhirat sebagai tujuan kepemimpinan Islam. Berdasarkan uraian di atas, dapat ditegaskan bahwa, kepemimpinan Islam adalah suatu proses atau kemampuan orang lain untuk mengarahkan dan memotivasi tingkah laku orang lain, serta ada usaha kerja sama sesuai dengan Al-Qur'an dan Hadis untuk mencapai tujuan yang diinginkan bersama.
\end{abstract}

Kata Kunci: Kepemimpinan dan perpsektif Islam

\section{A. Pendahuluan}

Setiap Pemimpin memiliki kerinduan untuk membangun dan mengembangkan mereka yang dipimpinnya sehingga tumbuh banyak 
Vol. V, No. 1, April 2017

pemimpin dalam kelompoknya. Keberhasilan seorang pemimpin sangat tergantung dari kemampuannya untuk membangun orang-orang disekitarnya, karena keberhasilan sebuah organisasi sangat tergantung pada potensi sumber daya manusia dalam organisasi tersebut. Jika sebuah organisasi atau masyarakat mempunyai banyak anggota dengan kualitas pemimpin, organisasi atau bangsa tersebut akan berkembang dan menjadi kuat.

Menjadi pemimpin melekat pada dirinya sifat melayani, memiliki rasa kasih sayang dan perhatian kepada mereka yang dipimpinnya, kasih itu mewujud dalam bentuk kepedulian akan kebutuhan, kepentingan, impian, dan harapan dari mereka yang dipimpinnya. Sementara itu kepemimpinan merupakan suatu proses mempengaruhi kegiatan-kegiatan kelompok yang terorganisasi dalam usaha-usaha menetukan tujuan dan pencapaiannya.

\section{B. Konsep Dan Definisi Kepemimpinan}

Persoalan kepemimpinan memiliki usia yang sama tuanya dengan sejarah manusia. Sesuai prinsip "Primus Interpares" dimana dalam setiap lingkungan masyarakat, organisasi formal maupun non formal selalu ada seseorang yang dianggap "lebih dari yang lain", kemudian diangkat dan dipercaya untuk mengatur yang lain.

Sedikitnya terdapat empat alasan mengapa seorang pemimpin dibutuhkan. Pertama; secara alamiah manusia butuh untuk diatur. Kedua; dalam beberapa situasi seorang pemimpin perlu tampil mewakili kelompoknya. Ketiga; sebagai tempat pengambil alihan 
resiko apabila terjadi tekanan terhadap kelompoknya. Keempat; sebagai tempat untuk meletakkan kekuasaan. ${ }^{1}$

Istilah kepemimpinan, dalam kamus bahasa Indonesia berasal dari kata "pimpin” yang mempunyai arti "dibimbing”. Sedangkan kata pemimpin itu sendiri mempunyai makna "orang yang memimpin." Jadi kepemimpinan adalah cara untuk memimpin. ${ }^{2}$

Terkait dengan definisi ini, Muhammad Ryaas Rasyid mengatakan bahwa pemimpin bisa diartikan seseorang yang terus menerus membuktikan bahwa ia mampu mempengaruhi sikap dan tingkah laku orang lain. ${ }^{3}$ Dari sini dapat dipahami bahwa kepemimpinan adalah sebuah konsep yang merangkum berbagai segi, diantaranya adalah proses interaksi antara pemimpin dan yang dipimpin dalam mengejar tujuan bersama.

Kepemimpinan dapat juga diartikan sebagai proses atau kemampuan mempengaruhi, memberi inspirasi, dan mengarahkan tindakan seseorang atau kelompok melalui proses komunikasi untuk mencapai tujuan yang diharapkan. Seperti yang diungkapkan Edwin A. Fleishman;

"Leadership is an attempt at influencing the activities of followers through the communication process and toward the affair meant of some goals". 4

${ }^{1}$ Veithzal Rivai, Kepemimpinan dan Perilaku Organisasi, (Jakarta: PT Raja Grafindo Persada, 2004), Cet. ke-2, h. 1-2

${ }^{2}$ Lihat, Depdikbud, Kamus Besar Bahasa Indonesia, (Jakarta: Balai Pustaka, 1994), cet. ke-4,h. 967

${ }^{3}$ Muhammad Ryaas Rasyid, Makna Pemerintahan Tinjauan dari Segi Etika dan Kepemimpinan, (Jakarta: PT. Yarsif Watampone, 1997), Cet. ke-3, h. 75

${ }^{4}$ Edwin A. Fleishman \& James G. Hunt, Current Development in Study of Leadership, (Carbondale: Southern Illinois University Press., 1973), h. 3 
Vol. V, No. 1, April 2017

Adakalanya kepemimpinan dipahami sebagai kemampuan untuk menggerakkan orang lain atau sebagai alat, sarana dan proses untuk membujuk orang atau kelompok agar bersedia melakukan sesuatu secara sukarela, tanpa kekuatan paksaan.

"Leadership is an individual attempt to affect the behavior of a group without using the coercive form power". 5

Kepemimpinan diidentikkan pula dengan proses mengarahkan dan mempengaruhi aktivitas-aktivitas yang ada hubungannya dengan pekerjaan para anggota kelompok. Tiga implikasi penting yang terkandung dalam hal ini adalah, Pertama; kepemimpinan melibatkan orang lain baik itu bawahan maupun pengikut. Kedua; kepemimpinan melibatkan pendistribusian kekuasaan antara pemimpin dan anggota kelompok secara seimbang. Ketiga; adanya kemampuan untuk menggunakan bentuk kekuasaan yang berbeda untuk mempengaruhi tingkah laku pengikutnya. ${ }^{6}$

Secara keseluruhan pembahasan tersebut telah mengungkap beberapa hal penting dalam kepemimpinan yaitu :

1. Adanya pemimpin dan orang lain yang dipimpin.

2. Adanya upaya atau proses mempengaruhi dari pemimpin kepada orang lain melalui berbagai kekuatan.

3. Adanya tujuan akhir yang ingin dicapai.

4. Kepemimpinan bisa timbul di dalam atau di luar organisasi tertentu.

${ }^{5}$ James L. Gibson, John M. Ivancevich \& James H. Donnelly, Organization: Behavior, Structure and Processes, Edisi 5, (Texas: Business Publication Inc. 1985), h. 362 .

${ }^{6}$ Veithzal Rivai, Kepemimpinan dan Perilaku Organisasi... h. 4. 
5. Kepemimpinan berbeda dalam situasi tertentu baik situasi pengikut ataupun lingkungan eksternal. ${ }^{7}$

\section{Tugas dan Gaya Kepemimpinan}

1. Tugas pemimpin

Kepemimpinan merupakan hasil organisasi sosial yang didalamnya berlangsung dinamika interaksi sosial. Dalam struktur masyarakat sederhana munculnya seorang pemimpin tidak pernah jauh dari pengambilan peran yang dilakukan. ${ }^{8}$ Keberadaan pemimpin sangat diperlukan dalam keadaan dimana tujuan kelompok mengalami ancaman dari lingkungan luar. Disinilah peran pemimpin sebagai pengambil keputusan diharapkan mampu membawa kelompoknya keluar dari berbagai kesulitan.

Dalam sudut pandang sosiologis, secara keseluruhan terdapat tiga tugas pokok pemimpin. Pertama; Memberikan suatu kerangka pokok yang jelas dan dapat dijadikan pegangan bagi para pengikutnya. Dengan adanya kerangka tersebut, maka dapat disusun suatu skala prioritas mengenai keputusan-keputusan yang perlu diambil guna menanggulangi persoalan yang dihadapi (yang sifatnya potensial atau nyata). Apabila timbul pertentangan, maka kerangka pokok tersebut dapat digunakan sebagai pedoman untuk menyelesaikannya. Kedua; Mengawasi, mengendalikan serta

\section{${ }^{7}$ Ibid., h. 9}

${ }^{8}$ David Krech \& Richard S. Crutshfield, Theory and Problem of Social Psychology, (NY: Mc Grow Hill Book Company Inc., 1948), h. 434 
Vol. V, No. 1, April 2017

mengarahkan perilaku para pengikutnya. Ketiga; Bertindak sebagai wakil kelompok kepada dunia luar. ${ }^{9}$

2. Gaya kepemimpinan

Gaya kepemimpinan merupakan norma perilaku yang digunakan pada saat seseorang mencoba mempengaruhi perilaku orang lain. Dalam hal ini usaha menyelaraskan persepsi diantara orang yang akan mempengaruhi dan dipengaruhi menjadi amat penting kedudukannya. Terkait hal ini, Soerjono Soekanto mengungkap bahwa terdapat tiga gaya kepemimpinan yang lazim digunakan, yaitu otoriter, demokratis dan cara-cara bebas.

a. Otoriter, dengan ciri pokok

1) Pemimpin melakukan segala kegiatan kelompok secara sepihak.

2) Pengikut sama sekali tidak diajak untuk ikut serta merumuskan tujuan kelompok dan cara-cara untuk mencapainya.

3) Pemimpin terpisah dan seakan-akan tidak ikut dalam proses interaksi dalam kelompok tersebut.

${ }^{9}$ Soerjono Soekanto, Sosiologi: Suatu Pengantar, (Jakarta: PT Raja Grafindo Persada, Cet. ke-37, 2004), h. 294. 
b. Demokratis, dengan ciri umum

1) Secara musyawarah dan mufakat pemimpin mengajak para pengikut untuk ikut serta merumuskan tujuan serta cara-cara mencapainya.

2) Pemimpin secara aktif memberikan saran dan petunjuk

3) Ada timbal balik kritik positif.

4) Pemimpin secara aktif ikut ambil bagian dalam kegiatankegiatan kelompok.

c. Cara-cara bebas, dengan ciri

1) Pemimpin menjalankan perannya secara pasif

2) Penentuan tujuan yang akan dicapai sepenuhnya diserahkan kepada kelompok.

3) Pemimpin hanya menyediakan sarana yang diperlukan kelompok

4) Pemimpin berada ditengah-tengah kelompok, namun tidak lebih dari seorang penonton.

Kemudian yang perlu dipahami bahwa, pada hakekatnya ketiga kategori tersebut tidak bersifat mutlak terpisah, akan tetapi secara simultan ataupun kombinasi ketiganya dapat diterapkan, tergantung situasi dan kondisi yang dihadapi.

\section{Kekuasaan, Wewenang, Kepemimpinan dan Manajemen.}

Kepemimpinan, kekuasaan, wewenang dan manajemen merupakan beberapa konsep yang terkadang dianggap memiliki batasan kabur dan tidak jelas. Bahkan dalam beberapa kondisi, keempat konsep tersebut melebur dalam satu ikatan yang sangat erat. Akan tetapi 
Vol. V, No. 1, April 2017

sebagai sebuah konsep yang terpisah, pada prinsipnya terdapat perbedaan mendasar dan spesifik antara keempatnya.

Kekuasaan pertama kali didefinisikan oleh sosiologi Max Weber. Dia merumuskan kekuasaan sebagai suatu kemungkinan yang membuat seorang aktor di dalam suatu hubungan sosial dalam suatu jabatan untuk melaksanakan keinginannya sendiri dan yang menghilangkan halangan. ${ }^{10}$

Walter Nord merumuskan kekuasaan sebagai suatu kemampuan untuk mempengaruhi aliran, energi dan dana yang tersedia untuk mencapai suatu tujuan yang berbeda secara jelas dari tujuan lainnya. ${ }^{11}$

Rogers berusaha membuat jelas kekaburan istilah dengan menganggap kekuasaan sebagai potensi dari suatu pengaruh. ${ }^{12}$ Demikian pula Griffin menyatakan "Power is the potential ability to affect the behavior of other" atau kekuasaan adalah kemampuan potensial untuk mempengaruhi perilaku orang lain. ${ }^{13}$

Dengan demikian, kekuasaan tidak lain merupakan suatu sumber yang bisa atau tidak bisa digunakan. Penggunaan kekuasaan selalu mengakibatkan perubahan dalam kemungkinan bahwa seseorang atau kelompok akan mengangkat suatu perubahan perilaku yang diinginkan.

${ }^{10}$ Miftah Thoha, Kepemimpinan dan Manajemen, (Jakarta: PT RajaGrafindo Persada, 2004), h. 92.

11 Walter Nord, Dream of Humanization and Realities, Academy of Management Review, (July, 1987), h. 675.

12 M.F. Rogers, Instrumental and Infra Resource: The Bases Power, (American Journal of Sociology, 79, 6, 1973), h. 1418

${ }^{13}$ Ricky W. Griffin, Management, Edisi 2, (Massachusetts: Houghton Mifflin Company, 1976), h. 421. 
Hal yang kemudian disebut dengan pengaruh (influence) ini, biasanya memiliki ruang lingkup lebih sempit dibanding kekuasaan itu sendiri.

Selanjutnya Max Weber mendefinisikan wewenang sebagai suatu hak yang telah ditetapkan dalam suatu tata tertib sosial untuk menetapkan kebijaksanaan, menentukan keputusan-keputusan mengenai persoalan penting dan untuk menyelesaikan pertentangan. ${ }^{14}$ Dengan lain perkataan, seorang yang mempunyai wewenang bertindak sebagai pembimbing bagi yang lain. Jadi penekanan yang ada adalah terletak pada hak dan bukan pada kekuatan.

Kepemimpinan seperti yang telah dirumuskan di depan ialah suatu proses untuk mempengaruhi aktivitas-aktivitas individu atau kelompok untuk mencapai tujuan dalam situasi tertentu. Kepemimpinan ada yang bersifat formal (resmi), karena suatu jabatan tertentu dan ada pula kepemimpinan non formal (tidak resmi), karena pengakuan masyarakat.

Sekilas, batasan ketiga konsep tersebut memiliki kesamaan, namun perlu dipahami bahwa kekuasaan berbeda dengan kepemimpinan dalam beberapa hal. Pertama; apabila kepemimpinan didefinisikan sebagai kemampuan mempengaruhi, maka kekuasaan adalah potensi dari pengaruh tersebut. Dengan kekuasaan seorang pemimpin mendapatkan hak untuk mengajak atau mempengaruhi orang lain. ${ }^{15}$ Kedua; kekuasaan tidak menuntut kompatibilitas tujuan, dan

${ }^{14}$ Soerjono Soekanto, Sosiologi: Suatu Penganta... h. 297.

${ }^{15}$ Miftah Thoha, Kepemimpinan dan Manajemen...h. 93. 
Vol. V, No. 1, April 2017

hanya sekedar menuntut ketergantungan. Di lain pihak, kepemimpinan menuntut kongruensi antara tujuan pemimpin dan pengikutnya. ${ }^{16}$

Selanjutnya wewenang atau sering juga disebut sebagai otoritas, merupakan tipe khusus dari kekuasaan yang secara natural melekat pada jabatan yang diduduki oleh pemimpin. Dengan demikian, secara ringkas dapat dirumuskan bahwa wewenang adalah kekuasaan yang disahkan (legitimized) oleh peranan formal dalam suatu organisasi. Dalam hal ini griffin mengungkapkan "Authority is power created and granted by an organization". ${ }^{17}$

Di sisi lain, istilah Manajemen berdiri sebagai sebuah konsep tersendiri dengan hubungan yang juga tidak terlalu jauh. Keberadaan konsep Manajemen dipandang lebih dekat kepada kepemimpinan. Hal ini dimana oleh Miftah Thoha keduanya diungkap bahwa Manajemen adalah kegiatan husus dari kepemimpinan. Atau dalam rumusan sederhana, Manajemen adalah kepemimpinan formal yang dibatasi oleh tata krama birokrasi dalam suatu organisasi. ${ }^{18}$

\section{E. Kepemimpinan dalam Perspektif Islam dan Dasar Konseptualnya.}

Di dalam Islam konsep kepemimpinan sering disebut dengan khalifah yang berarti wakil. Namun kemudian mengalami pergeseran dengan masuknya kata amir atau penguasa. Oleh sebab itu kedua istilah

\footnotetext{
${ }^{16}$ Stephen P.Robbin, Organization Behavior, "Prilaku Organisasi” Buku 2, (Gramedia, 2003), h. 93

${ }^{17}$ Ricky W. Griffin, Management, Edisi 2, h. 421

${ }^{18}$ Miftah Thoha, l Kepemimpinan dan Manajemen...h.93
} 
ini dalam bahasa Indonesia sering diasumsikan sebagai pemimpin formal. Akan tetapi, apabila merujuk kepada firman Allah swt. Dalam surat al Baqarah ayat 30 yaitu :

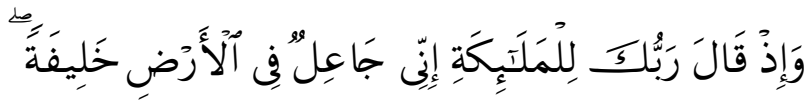

“(Ingatlah) ketika Tuhanmu berfirman kepada para Malaikat, "Sesungguhnya Aku Hendak menjadikan seorang Khalifah di muka Bumi". (Al Baqarah: 30) ${ }^{19}$

Maka kedudukan nonformal dari seorang khalifah juga tidak bisa dipisahkan lagi. Perkataan khalifah dalam ayat tersebut tidak hanya ditujukan kepada para khalifah sesudah Nabi, tetapi adalah penciptaan Nabi Adam a.s. yang disebut sebagai manusia dengan tugas untuk memakmurkan bumi dan meliputi tugas menyeru orang lain berbuat amar ma'ruf dan mencegah perbuatan mungkar.

Ayat ini mengisyaratkan bahwa, pada prinsipnya boleh-boleh saja seseorang memohon kepada Allah agar dijadikan imam (pemimpin). Karena ia memohon kepada Allah maka harus menjalankan kepemimpinannya sesuai kemauan Allah. Yang dilarang adalah orangorang meminta jabatan dan tidak dapat menjalankan, karena tidak mempunyai potensi dan kemampuan.

Ibnu Khaldun berpendapat bahwa khalifah merupakan beban bagi umat sepanjang pandangan syara' untuk kemaslahatan akhirat dan dunia yang akan kembali lagi. Sebab hal yang bersifat duniawi menurut syara' semuanya dapat diibaratkan untuk kemaslahatan akhirat. Maka

${ }^{19}$ QS:Al-Baqoroh:30 
Vol. V, No. 1, April 2017

dari sini dipahami bahwa dalam hakekatnya khalifah adalah pengganti pemimpin syari'at (Nabi Muhammad saw) dalam memelihara Agama dan dunia. ${ }^{20}$

Sebagaimana yang diungkapkan dalam hadis yang diriwayatkan oleh Zahya bin Zahya dari Mughirah bin Abdurrahman al-Hizami dari Abu Zinad dari al- A'raj dari Abu Hurairah dari Rasulullah saw. Beliau bersabda :

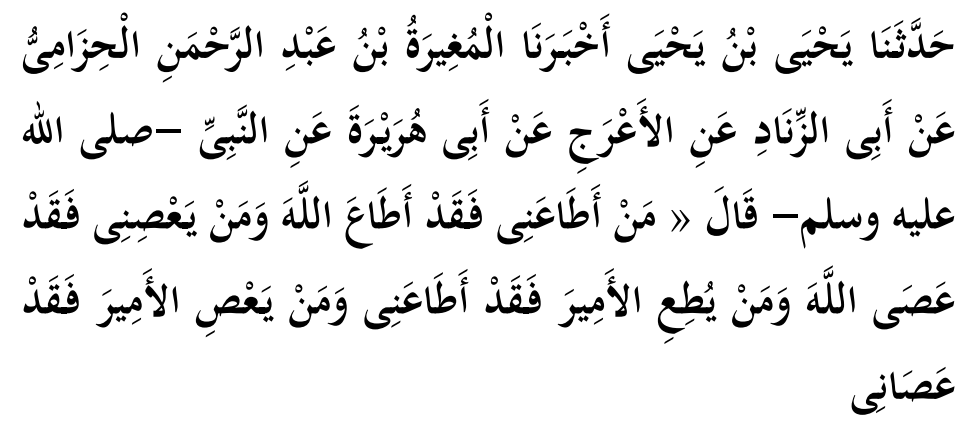

Artinya: "Barang siapa yang taat kepadaku, niscaya Dia taat kepada Allah. Dan barang siapa yang durhaka kepadaku, niscaya dia akan durhaka kepada Allah. Barang siapa yang taat kepada pemimpin, niscaya dia akan taat kepadaku. dan barang siapa durhaka kepada pemimpin, niscaya dia durhaka kepadaku". ${ }^{21}$

Selain kata khalifah, konsep kepemimpinan dalam al-Qur'an juga biasa disebut dengan kata Imam. Kata Imam merupakan derivasi dari kata Amma-Ya'ummu yang berarti menuju, menumpu atau meneladani. Dari akar kata yang sama, lahir juga kata yang antara lain adalah umm yang berarti Ibu dan imam yang maknanya juga pemimpin, karena

${ }^{20}$ Ibnu Khaldun, Muqoddimah, (Beirut: Dar al- Fikr, tt), h. 134

${ }^{21}$ Shahih Muslim, hadits no 纟^or Juz II, (Lebanon: Dar Al Kutub Beirut, t.t), h.129. 
keduanya menjadi teladan, tumpuan pandangan dan harapan. Ada juga yang berpendapat kata imam pada mulanya berarti cetakan seperti cetakan untuk membuat sesuatu yang serupa bentuknya dengan cetakan itu. Dari sini Imam diartikan teladan. ${ }^{22}$

Abu Zahrah berpendapat bahwa imamah dan khilafah merupakan kesamaan arti. Dia mengatakan "bahwa imamah juga disebut khalifah, sebab orang yang menjadi khilafah adalah penguasa tertinggi bagi umat Islam yang mengerti. Khilafah juga disebut imam, sebab para khilafah adalah pemimpin yang wajib di ikuti. ${ }^{23}$

Selanjutnya digunakan pula istilah Ulil Amri yang satu akar dengan kata Amir sebagaimana disebutkan di atas. Kata Ulil Amri berarti pemimpin tertinggi dalam masyarakat Islam, ${ }^{24}$ seperti firman Allah swt dalam surat an Nisa' ayat 59.

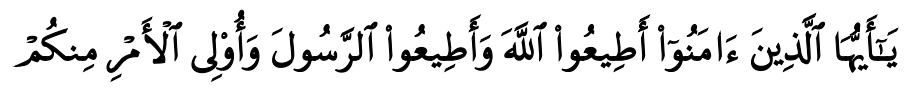

Hai orang-orang yang beriman taatilah Allah dan taatilah Rasul Nya dan Ulil Amri diantara kamu. (Al Nisa': 59) ${ }^{25}$

Dalam al Qur'an ada pula istilah Auliya' yang berarti pemimpin yang sifatnya resmi dan tidak resmi. Sesuai dengan firman Allah surat al-Maidah ayat 55 .

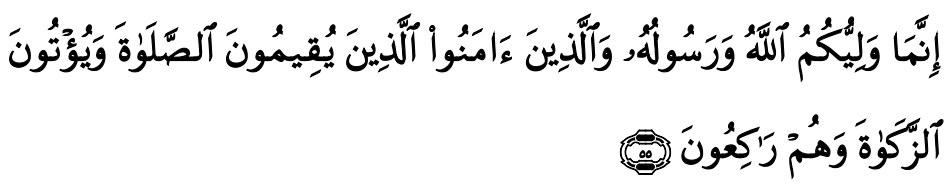

${ }^{22}$ M. Quraish Shihab, Tafsir Al-Misbah: Pesan dan Kesan Keserasian alQur'an, (Jakarta: Lentera Hati, , 2004), Volume I, Cet. ke-2, h. 545

23 Ali Ahmad as Salus, Aqidah Al- Imamah, 'Inda as-Syari'ah al-Isna 'Asyariyah, (Jakarta: Gema Insani Press., 1987), Cet. ke-1, h. 16.

${ }^{24}$ Veithzal Rivai, Kepemimpinan dan Perilaku Organisasi... h. 5

${ }^{25}$ QS:An-nisa:59 
Vol. V, No. 1, April 2017

Sesungguhnya penolong kamu hanyalah Allah, Rasulnya, dan orang-orang yang beriman, yang mendirikan Sholat dan menunaikan Zakat seraya mereka tunduk kepada Allah. (AlMaidah: 55) ${ }^{26}$

Dalam hadis Rasulullah saw. Istilah pemimpin dijumpai dalam kata $R a^{\prime} i n$, seperti dalam sebuah hadits ..... راع كلكم (Setiap orang diantara kamu adalah pemimpin). Dari uraian al-Qur'an dan Hadis di atas hal yang dapat digaris bawahi, adalah bahwa kepemimpinan Islam merupakan kegiatan menuntun, membimbing, memandu dan menunjukkan jalan yang diridloi Allah swt. Kemudian dalam rangka memahami dasar konseptual kepemimpinan dalam perspektif Islam paling tidak harus digunakan tiga pendekatan yaitu normatif, historis dan teoritis. ${ }^{27}$

1. Pendekatan Normatif

Dasar konseptual kepemimpinan Islam secara normatif bersumber pada al-Qur'an dan Hadis yang terbagi atas empat prinsip pokok.

a. Prinsip tanggung jawab dalam organisasi

Dalam Islam telah digariskan bahwa setiap manusia adalah pemimpin (minimal untuk dirinya sendiri) dan untuk kepemimpinan tersebut ia dituntut bertanggung jawab. Tanggung jawab disini adalah substansi utama yang harus dipahami terlebih dahulu oleh seorang calon pemimpin agar amanah yang diserahkan kepadanya tidak disia-siakan.

${ }^{26}$ QS:Almaidah:55

${ }^{27}$ Ibid. 


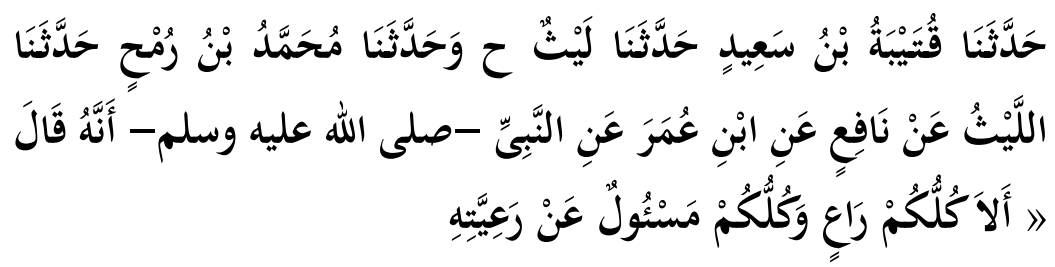

"Dari Qutiabah bin Said dari Laits, Saya juga di ceritai oleh Muhammad bin Rumhi dari laits dari Nafi dari Ibn Umar bahwa Rasullulah SAW berkata: "Setiap kalian adalah pemimpin, dan setiap kalian akan ditaya tentang kepemimpinannya, penguasa adalah pemimpin dan akan ditanya tentang kepemimpinannya." 28

b. Prinsip Etika Keadilan

Untuk menjaga keseimbangan kepentingan, maka asas keadilan harus benar-benar dijaga agar tidak muncul stigmastigma ketidakadilan seperti kelompok marginal dan lain-lain. Firman Allah swt dalam surat Shad ayat 26.

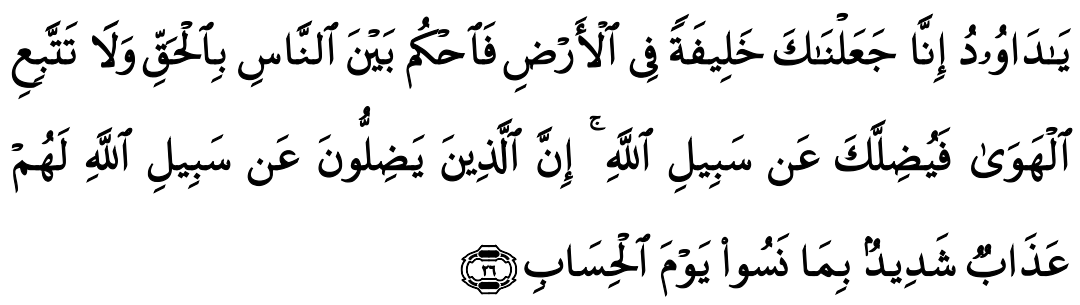

Hai Daud, sesungguhnya kami menjadikan kamu Khalifah (penguasa) dimuka bumi, maka berilah keputusan (perkara) diantara manusia dengan adil dan janganlah kamu mengikuti hawa nafsu, karena ia akan menyesatkan kamu dari jalan Allah. Sesungguhnya orang-orang yang sesat dari jalan Allah akan mendapat azab yang berat, karena mereka melupakan hari perhitungan. ( Shad : 26 )

Firman Allah dalam Qs Al Ma'idah ayat 49.

${ }^{28}$ Lihat Muslim, Shahih Muslim, Juz II hadits no $\_\wedge \uparrow \wedge .$. h. 125. 


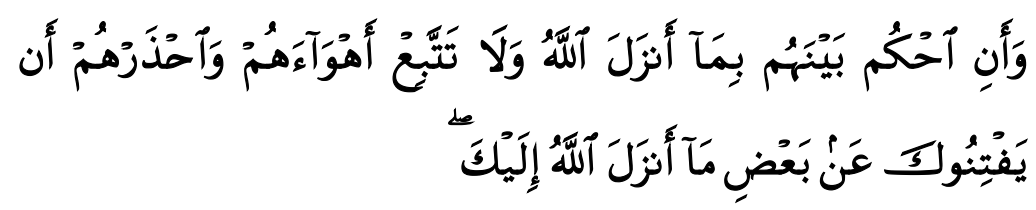

"Dan putuskanlah perkara di antara mereka dengan apa yang diturunkan Allah dan janganlah engkau mengikuti hawa nafsu mereka. Dan berhati-hatilah kamu terhadap mereka supaya mereka tidak memalingkan kamu dari apa yang telah diturunkan Allah kepadamu." (QS. Al-Ma'idah: 49). ${ }^{29}$

c. Prinsip Kesederhanaan

Rasulullah menegaskan bahwa seorang pemimpin harus melayani dan tidak meminta untuk dilayani (خادمهم القوم رئيس)

\section{Pendekatan Historis}

Al-Qur'an begitu kaya dengan kisah-kisah umat masa lalu sebagai pelajaran dan bahan perenungan bagi umat yang akan datang. Dengan pendekatan historis ini diharapkan lahir pemimpinpemimpin Islam yang memiliki sifat sidik, amanah, fathonah,tabligh, dan lain-lain, sebagai syarat keberhasilannya dalam memimpin. Kisah-kisah dalam al-Qur'an, Hadis, sirah nabawiyah serta sirah sahabat telah memuat berbagai pesan moral yang tak ternilai harganya.

3. Pendekatan Teoritis

Ideologi Islam adalah ideologi terbuka dan dialektis. Hal ini mengandung arti walaupun dasar-dasar konseptual yang ada sudah sempurna, namun Islam tidak menutup kesempatan untuk mengkomunikasikan ide-ide dan pemikiran-pemikiran dari luar

${ }^{29}$ QS:Al-Maidah:49 
selama pemikiran tersebut tidak bertentangan dengan al-Qur'an dan Sunnah Rasulullah. ${ }^{30}$

Pengembangan ilmu pengetahuan, kerangka manajemen Islam selama berada dalam koridor ilmiah tentunya sangat dianjurkan mengingat kompleksitas permasalahan dari zaman ke zaman akan selalu bertambah. Sejarah Islam pun mencatat dalam setiap zaman selalu lahir pembaharu-pembaharu pemikiran Islam yang membangun dasar dasar konseptual yang relevan dengan zamannya.

Teori tentang kemunculan seorang pemimpin dalam masyarakat Islam tidak berbeda dengan teori umum yang berkembang sebagaiman telah dikemukakan pada bagian awal. Hal ini dapat dilihat dari beberapa pandangan utama dalam masyarakat Islam tentang siapa yang layak menyandang predikat seorang pemimpin Islam sebagai agama yang tidak bebas dari sistem nilai budaya tempat dimana Islam itu bermula. Banyak pakar yang beranggapan bahwa Arab dan Islam memiliki hubungan yang sangat erat, keduanya saling mempengaruhi sehingga sedikit banyak Islam dipengaruhi oleh Arab dan demikian juga sebaliknya Arab banyak dipengaruhi Islam.

Dalam Kaitan ini, perlu dipahami mengapa tradisi Arab sebelum Islam yang berkaitan dengan kepemimpinan masih melekat kuat dalam masyarakat Arab. Masyarakat Arab Makkah percaya bahwa pemimpin itu lahir dari suku yang paling utama,

${ }^{30}$ Veithzal Rivai, Kepemimpinan dan Perilaku Organisasi... h 23 
Vol. V, No. 1, April 2017

yakni suku Quraisy. Namun tidak hanya itu, mereka juga mengakui consensus akan pengangkatan seorang pemimpin dalam masyarakat Arab Islam, bahkan hingga kini, terbagi kepada dua hal. Pertama, Teori keturunan (berdasarkan klan, qabilah),dan Kedua, Teori sosial (social consensus).

Pada teori yang pertama, masyarakat Islam percaya bahwa bangsa Arab adalah seorang yang memiliki bakat kepemimpinan yang kuat. Hal ini disebabkan kekuatannya dalam menghafal, kekuatan fisiknya, dan keberaniannya. Tidak hanya itu, secara kultural umat Islam mendasarkannya dengan beberapa pemimpin religius yang memainkan peranan dalam panggung sejarah umat Islam adalah orang Arab. Adapun keyakinan orang Arab mekkah pada masa sebelum Islam yang memandang Quraisy sebagai suku yang paling mulia dan utama adalah disebabkan oleh sifat amanahnya yang menjaga dan melindungi ka'bah selama bertahuntahun. Ka'bah sendiri memiliki pengaruh tertentu pada masyarakat Mekkah pada masa itu.

Teori kedua, Konsensus sosial. Kasus ini dapat dilihat dari penunjukan Muhammad sebagai orang yang dipercaya semua pemuka kabilah. Muhammad pada Saat itu hanyalah seorang remaja yang belum memiliki pengaruh apapun, namun dengan berbagai pertimbangan, semua kabilah ini mempercayai Muhammad untuk mengambil keputusan manakala terjadi perselisihan diantara kabilah-kabilah untuk meletakkan kembali hajar aswad yang jatuh 
dari tempatnya. Peristiwa inilah yang kemudian menyebabkan Muhammad diberi gelar Al-Amin artinya orang yang terpercaya. ${ }^{31}$

Kedua fenomena ini dapat dijadikan acuan dasar untuk memahami teori kemunculan seorang pemimpin dalam masyarakat Islam. Dengan begitu, meskipun tidak berada dalam masyarakat Arab, umat Islam dapat menentukan seorang pemimpin yang berdasarkan konsensus sosial atau kesepakatan berdasarkan musyawarah dengan didasarkan pada beberapa kriteria tertentu.

\section{F. Tipologi Ideal Kepemimpinan Islam}

Sebagaiman telah dikemukakan diatas bahwa sesungguhnya tidak ada kepemimpinan ideal yang menunjuk pada suatu tipe saja, namun pemimpin ideal atau pemimpin efektif yang sanggup menyesuaikan diri dan organisasinya dengan lingkungan yang dihadapinya.

Kendatipun demikian, konsep idealis itu dapat difahami dalam empat kata kunci Keadilan ( ( qisth, equalizing, leveling ), Amanah (accountability), dakwah (socility), dan ummah (collectivity) yang akan melahirkan konsep " cvilleadership " atau kepemimpinan yang terwujud dan diperkuat dengan konsep keummatan. Oleh karena itu, untuk tetap melihat posisi manusia sebagai makhluk yang paling mulia yang dipilih Tuhan sebagai pengelola alam ini, maka setidaknya, dapat diindentifikasi beberapa prinsip pokok dalam kepemimpinan islam secara konseptual, dan hubungan-hubungan antar individu atau antar kelompok dalam konteks praktis.

1. Prinsip pertama: saling menghormati dan memuliakan

${ }^{31}$ Ibid., h. 86. 
Vol. V, No. 1, April 2017

sebagaimana Allah telah memuliakan Manusia.

2. Prinsip kedua : Menyebarkan Kasih sayang

Hal ini merupakan eksplorasi dari risalah Islam sebagai ajaran yang utuh, karena dia datang sebagai rahmat untuk seluruh alam ( rahmatan lil'alamin)

3. Prinsip Ketiga : Keadilan

Secara teologis, salah satu golongan yang dijanjikan memperoleh ganjaran surga adalah pemimpin yang adil.

4. Prinsip keempat: Persamaan

Prinsip ini adalah cabang dari prinsip sebelumnya yaitu keadilan, persamaan sangat ditekankan khususnya dihadapan hukum.

5. Prinsip Kelima : Perlakuan yang sama

Organisasi dihuni oleh orang-orang yang berbeda. Tidak hanya memiliki perbedaan sifat dan karakter, tetapi juga perbedaan latar belakang,

6. Prinsip keenam : Berpegang pada Akhlak yang utama.

Beberapa perilaku yang mencerminkan keutamaan, khususnya yang berkaitan dengan pergaulan hidup, lemah lembut, mudah memaafkan berlapang dada, bersabar gemar menolong.

7. Prisip ketujuh : Kebebasan

Islam adalah yang menghargai kebebasan, bahkan Islam tidak suka pemaksaan

8. Prinsip kedelapan : Menepati Janji

Dalam ajaran Islam, melarang mengingkari janji, janji merupakan hutang barang siapa yang mengingkari janji termasuk tanda orang munafik. ${ }^{32}$

${ }^{32}$ Ibid., h. 90. 


\section{G. Penutup}

Menjadi pemimpin adalah amanah yang harus dilaksanakan dan dijalankan dengan baik oleh pemimpin tersebut, karena kelak Allah akan meminta pertanggung jawaban atas kepemimpinannya itu.

Pemimpin merupakan titik sentral dan penentu kebijakan dari kegiatan yang akan dilaksanakan dalam organisasi. Kepemimpinan Islam adalah suatu proses atau kemampuan orang lain untuk mengarahkan dan memotivasi tingkah laku orang lain, serta ada usaha kerjasama sesuai dengan Al-Qur'an dan Hadis untuk mencapai tujuan yang diinginkan bersama. 
Vol. V, No. 1, April 2017

\section{DAFTAR PUSTAKA}

Abuddin Nata, 2002, Metodologi Studi Islam, Jakarta: Raja Grafindo Persada.

Anwar Ibrahim, 1996, Islam dan Pembentukan Masyarakat Madani", dalam Aswab Mahasin (ed.) Ruh Islam dalam Budaya Bangsa: Wacana antara Agama dan Bangsa, Jakarta: Yayasan Festival Istiqlal.

Departemen Agama RI, 2004, Al-Qur'an Dan Terjemahannya, Semarang: Toha Putra.

Depdikbud, 1994, Kamus Besar Bahasa Indonesia, Jakarta: Balai Pustaka, cet. ke-4.

Didin Hafidhuddin Tanjung \& Hendri, 2003, Manajemen Syari'ah dalam Praktek, Jakarta: Gema Insani Press.

Gibson, James L., John M. Ivancevich \& James H. Donnelly, 1985, Organization: Behavior, Structure and Processes, Edisi 5, Texas: Business Publication Inc.

Griffin, Ricky W, 1976, Management, Edisi 2, Massachusetts: Houghton Mifflin Company.

Hendricks, William, , 1996, How to Manage Conflic, Terj. Arif Santoso, "Bagaimana Mengelola Konflik", Jakarta : Bumi Aksara.

Ibn Hajaj, Imam Abi al-Husain, 1993, Shahih Muslim, terj. Adib Bisri Mustafa, "Shahih Muslim", Juz III, Semarang: Penerbit Assifa'.

Johnson, Doyle Paul, 1994, Sociological Theory: Classic and Modern, terj. Robert M. Z. Lawang "Teori Sosiologi Klasik dan Modern", Jakarta: PT Gramedia Pustaka Utama, Jilid I.

Khaldun, Ibnu, Muqoddimah, Beirut : Dar al- Fikr, tt.

Krech, David \& Richard S. Crutshfield, 1948, Theory and Problem of Social Psychology, NY: Mc Grow Hill Book Company Inc.

M. Quraish Shihab, 2004, Tafsir Al-Misbah: Pesan dan Kesan Keserasian alQur'an, Jakarta: Lentera Hati, volume. I, cet. Ke-2. 
Masykur Hakim \& Tanuwijaya, MA, 2003, Model Masyarakat Madani, Jakarta : Intimedia.

Miftah Thoha, 2004, Kepemimpinan dan Manajemen, Jakarta: PT RajaGrafindo Persada,

Noah, Webster, 1980, Webster New Twentieth Century Dictionary Unabridged, 2nd Ed., NY: William Collins Publishers Inc.

Nord, Walter, 1987, Dream of Humanization and Realities", Academy of Management Review, July.

Rasyid, Muhammad Ryaas, Makna Pemerintahan Tinjauan dari Segi Etika dan Kepemimpinan, Jakarta: PT. Yarsif Watampone, cet. Ke-3, 1997.

Robbins, Stephen P, 2002, Essential of Organizational Behavior, terj. Halida \& Dewi Sartika "Prinsip-prinsip Perilaku Organisasi", Edisi 5, Jakarta: Erlangga.

Rogers, M.F, , 1973, Instrumental and Infra Resource: The Bases Power, American Journal of Sociology, 79, 6.

Rus'an, Lintasan Sejarah Islam di zaman Rasulullah, Semarang: Penerbit Wicaksana.

Rusli, 2003, Sejarah Kebudayaan Islam, Semarang: Toha Putra.

Soerjono Soekanto, 2004, Sosiologi suatu Pengantar, Jakarta: PT Raja Grafindo Persada, Cet. ke-37.

T Hani Handoko, 1995, Manajemen, Edisi 2, Yogyakarta: BPFE UGM, Cet. Ke-9. 
82 | Jurnal Al-Afkar

Vol. V, No. 1, April 2017 